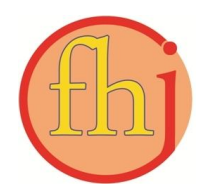

Faletehan Health Journal, 5 (3) (2018) 135-141

www. journal.Ippm-stikesfa.ac.id/ojs/index.php/FHJ

ISSN 2088-673X | e-ISSN 2597-8667

\title{
Analisis Faktor Yang Mempengaruhi Pemilihan Kelas Kepesertaan Jaminan Kesehatan Nasional
}

\author{
Rasdiawal Nur ${ }^{1}$, Ismail $A B^{1}$, Dina Lusiana $S^{1}$ \\ ${ }^{1}$ Fakultas Kesehatan M asyarakat, Universitas Mulawarman, Indonesia \\ *Corresponding Author: rasdhyy@gmail.com
}

\begin{abstract}
Abstrak
Akhir Tahun 2004 pemerintah menetapkan Undang-Undang No. 40 Tahun 2004 tentang Sistem Jaminan Sosial Nasional, dengan salah satu programnya adalah Jaminan Kesehatan Nasional (JKN). Diharapkan dengan adanya JKN pembiayaan pelayanan kesehatan masyarakat dilaksanakan dalam sistem asuransi dan JKN menjadi sistem jaminan yang bersifat wajib. Data dari Badan Penyelenggara Jaminan Sosial (BPJS) Kesehatan Kota Tarakan diketahui bahwa desa tertinggi yang terdaftar dalam BPJS Kesehatan adalah Desa Sei Pancang Kecamatan Sebatik Utara sebanyak 1.017 jiwa peserta mandiri. Penelitian ini bertujuan untuk mengetahui faktor-faktor yang memengaruhi masyarakat Desa Sei Pancang dalam pemilihan kelas kepesertaan JKN. Metode yang digunakan dalam penelitian ini adalah metode penelitian observasional dengan pendekatan cross sectional study. Populasi dalam penelitian ini adalah warga Desa Sei Pancang yang terdaftar sebagai peserta M andiri BPJS Kesehatan dengan sampel sebanyak 156 responden yang dipilih secara simple random sampling. Data dianalisis menggunakan uji univariat dan uji bivariat dengan Chi Square. Hasil analisis Chi Square menunjukkan adanya hubungan antara pendapatan ( $p$ value $=0,001$ ) dengan pemilihan kelas kepesertaan JKN dan tidak ada hubungan antara aksesibilitas ( $p$ value $=0,131$ ) serta mutu pelayanan ( $p$ value $=0,091$ ) dengan pemilihan kelas kepesertaan JKN. Dalam hal ini, diharapkan pihak BPJS Kesehatan melakukan sosialisasi kepada masyarakat tentang manfaat dan fasilitas yang didapatkan dalam setiap kelas kepesertaan JKN dan diharapkan masyarakat untuk memilih kelas kepesertaan JKN sesuai dengan pendapatan yang didapatkan demi terwujud pembiayaan kesehatan secara adil.
\end{abstract}

Kata Kunci: Aksesibilitas, Jaminan Kesehatan Nasional, M utu Pelayanan, Pendapatan

\begin{abstract}
At the end of 2004, the government established a law No.40 year 2004 about National Social Insurance System, with one of the program is National Health Insurance (JKN). This program is expected to carried out the financing of public health services in insurance system and becomes a mandatory insurance system. The data from branch of BPJS Kesehatan on Tarakan city showed the highest registered village on BPJS Kesehatan is SeiPancang village north Sebatik district with 1017 people of independent participants. The purpose of this study was to determine the factors that influenced people in SeiPancang village to choose JKN's membership class. This study used observational study method with cross sectional study design. Population in this study is people in SeiPancang village north Sebatik district who registered as independent participants of BPJS Kesehatan, with a sample of 156 selected respondents from simple random sampling. The data was analyzed using univariate test and bivariate test with chi square. The chi square analysis showed a correlation between income ( $p$ value $=0,001$ ) with choices of JKN's membership class, and no correlation between accessibility ( $p$ value $=$ 0,131 ) and services quality ( $p$ value $=0,091$ ) with choices of J KN's membership class. In this case, it is expected that the health bureau socializes to the public about the benefits and facilities obtained in each JKN participation class and it is expected that the community to choose the JKN membership class is in accordance with the income earned to achieve fair health financing.
\end{abstract}

Keywords: Accessibility, Income, Universal Health Covered, Services Quality 
Faletehan Health Journal, 5 (3) (2018) 135-141

www. journal.Ippm-stikesfa.ac.id/ojs/index.php/FHJ

ISSN 2088-673X| 2597-8667

\section{Pendahuluan}

Sistem Jaminan Sosial Nasional (SJSN) merupakan sebuah jaminan kesehatan yang diberlakukan di Indonesia. Akhir Tahun 2004 pemerintah menetapkan Undang-Undang No. 40 Tahun 2004 tentang Sistem Jaminan Sosial Nasional, dengan salah satu programnya adalah Jaminan Kesehatan Nasional (JKN). Diharapkan dengan adanya JKN pembiayaan pelayanan kesehatan masyarakat dilaksanakan dalam sistem asuransi dan JKN menjadi sistem jaminan yang bersifat wajib, besaran premi berdasarkan presentase pendapatan dan semua anggota mendapatkan pelayanan kesehatan yang sama. Melalui SJSN ini, seluruh masyarakat akan mendapatkan pelayanan kesehatan yang akan berdampak pada peningkatan derajat kesehatan. Undang-Undang No. 24 Tahun 2011 juga menetapkan, Jaminan Sosial Nasional akan diselenggarakan oleh Badan Penyelenggara Jaminan Sosial (BPJS), yang terdiri dari BPJS Kesehatan dan BPJS Ketenagakerjaan. Jaminan Kesehatan Nasional akan diselenggarakan oleh BPJS Kesehatan yang implementasinya dimulai 1 Januari 2014. Kepesertaan BPJS Kesehatan dibagi menjadi dua yaitu Penerima Bantuan Iuran (PBI) dan Bukan Penerima Bantuan Iuran. Iuran jaminan kesehatan bagi peserta pekerja bukan penerima upah dan bukan pekerja atau JKN Mandiri ditanggung oleh peserta yang bersangkutan dengan ketentuan sebesar Rp 25.500 per orang per bulan yang menghendaki pelayanan diruang perawatan kelas III, Rp 42.500 per orang bagi peserta yang menghendaki pelayanan diruang perawatan kelas II dan Rp 59.500 per orang yang menghendaki pelayanan diruang perawatan kelas I. Manfaat akomodasi dibedakan berdasarkan skala besaran iuran yang dibayarkan.

Penduduk Indonesia yang tercatat sebagai peserta BPJS Kesehatan sampai 1 April 2018 adalah 195.170.283 jiwa atau 76,39\% dari jumlah total populasi sekitar 255.466.700 juta penduduk Indonesia. Data tersebut menunjukkan upaya untuk mewajibkan masyarakat menjadi anggota JKN sampai saat ini belum bisa terlaksana sepenuhnya. Diperlukan sosialisasi yang menyeluruh agar masyarakat dapat berpartisipasi aktif dalam sistem jaminan kesehatan. Sosialisasi merupakan kunci keberhasilan pelaksanaan JKN mengingat tingkat kepesertaan jaminan kesehatan saat ini relatif rendah. Sosiaslisasi yang baik akan memberikan pemahaman dan kesadaran kepada peserta dan pemberi kerja akan hak dan kewajibannya (Peta Jalan JKN 2012-2019).

Provinsi Kalimantan Utara terdiri dari satu Kota dan empat Kabupaten, yaitu Kota Tarakan serta Kabupaten Bulungan, Malinau, Nunukan, dan Tana Tidung. Pulau Sebatik merupakan pulau terluar di Kabupaten Nunukan yang merupakan salah satu dari 92 pulau kecil dan terluar yang ada di Indonesia. Pulau yang berbatasan langsung dengan Malaysia ini secara administratif terbelah menjadi dua, sebagian masuk wilayah Indonesia dan sebagian lainnya masuk wilayah Malaysia. Pulau Sebatik terdiri dari 5 Kecamatan yang berbatasan langsung dengan negara tetangga Malaysia, 3 kecamatan berbatasan darat yaitu Kecamatan Sebatik Utara, Kecamatan Sebatik Tengah dan Kecamatan Sebatik Utara. Dua kecamatan lainnya berbatasan laut yaitu Kecamatan Sebatik Timur dan Kecamatan Sebatik. Kondisi geografis yang demikian menjadikan penduduk Pulau Sebatik tidak terlepas dari pengaruh kehidupan masyarakat tetangga khususnya imbas kemajuan ekonomi dari negara tetangga.

Berdasarkan data dari Badan Penyelenggara Jaminan Sosial (BPJS) Kesehatan Cabang Kota Tarakan tahun 2018 dari 47.709 jiwa jumlah masyarakat Pulau Sebatik, masyarakat yang telah menjadi peserta JKN-KIS adalah 13.852 peserta, 4.190 jiwa merupakan peserta mandiri. Dari data tersebut, desa tertinggi yang terdaftar dalam BPJS Kesehatan adalah Desa Sei Pancang Kecamatan Sebatik Utara sebanyak 2316 peserta, dengan rincian 1017 jiwa merupakan peserta mandiri dengan distribusi peserta terbanyak berada pada kelas kepesertaan kelas 3 yaitu 798 peserta, 134 peserta pada kelas 2 dan 85 peserta pada kelas 1 .

Hasil penelitian yang dilakukan di Provinsi Jambi menunjukkan bahwa ada hubungan antara tingkat pendapatan dengan pemilihan besar iuran BPJS Kesehatan (Noerjodianto, 2015). Hasil penelitian yang dilakukan di Puskesmas Sumber Rejo Kota Balikpapan menyatakan ada hubungan aksesibilitas terhadap pemanfaatan pelayanan kesehatan, dari hasil penelitian diperoleh OR 0,781 yang artinya responden yang menyatakan aksesibilitas mudah mempunyai peluang 0,781 untuk tidak memanfaatkan pelayanan kesehatan (Wahyuni, 2012). Penelitian yang dilakukan di Kota Semarang menjelaskan ada hubungan antara 
Faletehan Health Journal, 5 (3) (2018) 135-141

www. journal.Ippm-stikesfa.ac.id/ojs/index.php/FHJ

ISSN 2088-673X| 2597-8667

persepsi pasien terhadap kehandalan pelayanan dengan pemanfaatan ulang pelayanan kesehatan, dalam penelitian ini juga menjelaskan bahwa penilaian jasa pelayanan kesehatan lebih terkait pada tanggapan petugas memenuhi kebutuhan pasien, kelancaran komunikasi petugas dengan pasien serta kemampuan untuk memberikan pelayanan yang sesuai dengan janji yang ditawarkan (Trimurthy, 2008).

Berdasarkan latar belakang masalah di atas maka tujuan penelitian ini adalah untuk mengetahui faktor-faktor yang mempengaruhi pemilihan kelas kepesertaan JKN di Desa Sei Pancang Kecamatan Sebatik Utara Kabupaten Nunukan Kalimantan Utara.

\section{Metode Penelitian}

Jenis penelitian ini adalah penelitian observasional dengan pendekatan cross sectional. Penelitian dilakukan pada bulan Agustus 2018 di Desa Sei Pancang Kecamatan Sebatik Utara Kabupaten Nunukan Kalimantan Utara. Populasi penelitian adalah warga Desa Sei Pancang Kecamatan Sebatik Utara Kabupaten Nunukan Kalimantan Utara yang terdaftar sebagai peserta BPJS Mandiri, dengan jumlah 226 Kepala Keluarga, dengan sampel sebesar 156 peserta BPJS Mandiri. Teknik sampel yang digunakan adalah simple random sampling atau pengambilan sampel acak secara sederhana. Instrumen yang digunakan dalam penelitian ini adalah menggunakan lembar kuesioner yang telah dilakukan uji validitas dan uji reabilitas. Analisis data menggunakan uji chisquare dengan interpretasi pada CI 95\%, jika $p$ value $\leq 0,05$ maka Ho ditolak sehingga dapat dikatakan terdapat hubungan yang bermakna secara statistik.

\section{Hasil dan Pembahasan}

Pada penelitian ini karakteristik responden meliputi usia, jenis kelamin, pekerjaan, pendidikan, jumlah anggota keluarga, alamat rumah dan kelas kepesertaan JKN. Tabel 1 menunjukkan bahwa distribusi responden terbanyak berada pada kelompok usia 37 tahun hingga 46 tahun sebanyak 81 responden $(51,9 \%)$. Dari 156 responden, distribusi terbanyak memiliki jenis kelamin perempuan sebanyak 148 orang (94,9\%), dan distribusi responden terbanyak berdasarkan jenis pekerjaan sebanyak 110 orang (70,5\%) bekerja sebagai Ibu Rumah Tangga (IRT). Distribusi responden berdasarkan tingkat pendidikan dan kelas kepesertaan JKN, diketahui bahwa distribusi responden terbanyak berdasarkan tingkat pendidikan sebanyak 86 responden $(55,1 \%)$ mempunyai pendidikan SD/Sederajat. Serta distribusi responden terbanyak untuk kategori kelas kepesertaan JKN sebanyak 120 responden $(76,9 \%)$ berada pada kelas 3 kepesertaan JKN.

Tabel 1. Distribusi karakteritik responden

\begin{tabular}{lcc}
\hline \multicolumn{1}{c}{ Variabel } & F & \% \\
\hline Usia (Tahun) & & \\
$27-36$ & 43 & 27,6 \\
$37-46$ & 81 & 51,9 \\
$47-56$ & 32 & 20,5 \\
\hline Jenis Kelamin & & \\
Laki-laki & 8 & 5,1 \\
Perempuan & 148 & 94,9 \\
\hline Pekerjaan & & \\
Pegawai swasta & 14 & 9,0 \\
IRT & 110 & 70,5 \\
Nelayan & 6 & 3,8 \\
Petani & 8 & 5,1 \\
Berkebun & 11 & 7,1 \\
Wiraswasta & 6 & 3,8 \\
Lain-lain & 1 & 0,6 \\
\hline Pendidikan & & \\
Tidak & 16 & 10,3 \\
Sekolah/tidak & & \\
tamat SD & & \\
SD/sederajat & 86 & 55,1 \\
SMP/sederajat & 32 & 20,5 \\
SMA/sederajat & 11 & 7,1 \\
D3 & 9 & 5,8 \\
S1 & 2 & 1,3 \\
\hline Kelas Kepesertaan & &
\end{tabular}

\section{Kelas Kepesertaan}

JKN

$\begin{array}{ccc}\text { Kelas 1 } & 5 & 3,2 \\ \text { Kelas 2 } & 31 & 19,9 \\ \text { Kelas 3 } & 120 & 76,9\end{array}$

\begin{tabular}{lcc}
\hline Kategori Pendapatan & & \\
Kelas Bawah & 90 & 57,7 \\
Kelas Menengah & 65 & 41,7 \\
Kelas Atas & 1 & 0,6 \\
\hline Aksesbilitas & & \\
Akses Mudah & 155 & 99,4 \\
Akses Sulit & 1 & 0,6 \\
\hline Mutu Pelayanan & & \\
Mutu Kurang & 6 & 3,8 \\
Mutu Baik & 150 & 96,2 \\
\hline Total (n) & $\mathbf{1 5 6}$ & $\mathbf{1 0 0}$ \\
\hline
\end{tabular}


Distribusi responden berdasarkan kategori pendapatan, aksesibilitas dan mutu pelayanan diketahui bahwa distribusi responden terbanyak berada pada kategori pendapatan kelas bawah sebanyak 90 responden $(57,7 \%)$. akses mudah sebanyak 155 orang (99.4\%), dan mutu baik sebanyak 150 orang $(3.8 \%)$.

Berdasarkan tabel 2, untuk variabel pendapatan, dari 90 yang memiliki pendapatan kelas bawah sebanyak $85(54,5 \%)$ responden dengan kepesertaan kelas 3 . Variabel aksesibilitas dari 155 responden yang menyatakan akses mudah $120(76,9 \%)$ dengan kepesertaan kelas 3 dan variabel mutu pelayanan, dari 150 responden yang menyatakan mutu baik sebanyak $120 \quad(76,8 \%)$ responden dengan kepesertaan kelas 3.

Berdasarkan hasil uji Chi Square dalam menguji hubungan, didapatkan hasil untuk variabel pendapatan $p$ value $=<0,001$ nilai tersebut lebih kecil dari nilai $\alpha 0,05$ yang artinya ada hubungan antara pendapatan dengan kelas kepesertaan JKN, variabel aksesibilitias didapatkan hasil $p$ value $=$ 0,131 nilai tersebut lebih besar dari nilai $\alpha 0,05$ yang artinya tidak ada hubungan antara aksesibilitas dengan kelas kepesertaan JKN dan untuk variabel mutu pelayanan didapatkan hasil $p$ value $=0,091$ nilai tersebut lebih besar dari nilai $\alpha$ 0,05 yang artinya tidak ada hubungan antara mutu pelayanan dengan kelas kepesertaan JKN.

\section{Hubungan Pendapatan dengan Pemilihan Kelas Kepesertaan JKN}

Pendapatan merupakan ukuran yang sering digunakan untuk melihat kondisi status sosial ekonomi pada suatu kelompok masyarakat tertentu. Berdasarkan penggolongannya, pendapatan dibedakan menjadi tiga golongan yaitu, kelas menengah ke atas jika pendapatan $>$ Rp.6.000.000 per bulan, kelas menengah jika pendapatan pendapatan Rp.2.600.000Rp.6.000.000 per bulan dan kelas menengah ke bawah jika pendapatan <Rp.2.600.000 per bulan (BPPK Kemenkeu RI, 2015).

Kemampuan masyarakat dalam menentukan kelas perawatan dalam JKN sangat tergantung dari besar pendapatan yang didapatkan, dalam penelitian ini terbukti bahwa ada hubungan yang signfikan $(P$ Value $<0,001<\alpha 0,05)$ antara besar pendapatan dengan pemilihan kelas keperawatan dalam JKN. Hasil ini sejalan dengan penelitian Noerjodianto (2015) bahwasanya ada hubungan antara tingkat pendapatan terhadap pemilihan besaran iuran BPJS Kesehatan bagi calon peserta BPJS kesehatan. Dalam penelitian ini diketahui, $76.9 \%$ responden memilih perawatan kelas 3 dalam JKN dan $54.5 \%$ responden diantaranya berada pada ketegori pendapatan kelas menengah ke bawah, yang artinya $54.5 \%$ responden telah memilih kelas pelayanan sesuai dengan tingkat pendapatannya. Dalam penelitian Noerjodianto (2015) juga menjelaskan bahwa kecenderungan masyarakat dalam memilih besar iuran BPJS Kesehatan bergantung pada tingkat pendapatan, semakin tinggi pendapatan semakin tinggi seseorang ingin memperoleh pelayanan kesehatan yang terbaik dan semakin rendah pendapatan seseorang akan memperoleh pelayanan kesehatan yang sesuai dengan pendapatanya.

Tabel 2. Hubungan Pendapatan, Aksesibilitas dan Mutu Pelayanan dengan Pemilihan Kelas Kepesertaan JKN

\begin{tabular}{|c|c|c|c|c|c|c|c|c|c|}
\hline \multirow{3}{*}{ Variabel } & \multicolumn{6}{|c|}{ Kelas Kepesertaan JKN } & \multicolumn{2}{|c|}{ Total } & \multirow{3}{*}{$\begin{array}{l}p \text { value } \\
<0,001\end{array}$} \\
\hline & \multicolumn{2}{|c|}{ Kelas 1} & \multicolumn{2}{|c|}{ Kelas 2} & \multicolumn{2}{|c|}{ Kelas 3} & \multirow[b]{2}{*}{$\mathbf{n}$} & \multirow{2}{*}{$\%$} & \\
\hline & $\mathrm{N}$ & $\%$ & $\mathrm{n}$ & $\%$ & $\mathrm{n}$ & $\%$ & & & \\
\hline $\begin{array}{l}\text { Pendapatan } \\
\text { Kelas Bawah }\end{array}$ & 0 & 0 & 5 & 3.2 & 85 & 54.5 & 90 & 57.7 & \\
\hline Kelas Menengah & 5 & 3.2 & 26 & 16.7 & 34 & 21.8 & 65 & 41.7 & \\
\hline Kelas Atas & 0 & 0 & 0 & 0 & 1 & 0.6 & 1 & 0.6 & \\
\hline $\begin{array}{l}\text { Aksesiblitas } \\
\text { Akses Sulit } \\
\text { Akses Mudah }\end{array}$ & $\begin{array}{l}0 \\
5\end{array}$ & $\begin{array}{c}0 \\
3.2\end{array}$ & $\begin{array}{c}1 \\
31\end{array}$ & $\begin{array}{c}0.6 \\
19.2\end{array}$ & $\begin{array}{c}0 \\
120\end{array}$ & $\begin{array}{c}0 \\
76.9\end{array}$ & $\begin{array}{c}1 \\
155\end{array}$ & $\begin{array}{c}0.6 \\
99.4\end{array}$ & 0,131 \\
\hline Mutu Pelayanan & & & & & & & & & \\
\hline Mutu Kurang & 1 & 0.6 & 0 & 0 & 5 & 3.2 & 6 & 0.6 & 0,091 \\
\hline Mutu Baik & 4 & 2.6 & 31 & 19.9 & 115 & 73.6 & 150 & 96.2 & \\
\hline Total (n) & 5 & 3.2 & 31 & 19.9 & 120 & 76.8 & 156 & 100 & \\
\hline
\end{tabular}


Faletehan Health Journal, 5 (3) (2018) 135-141

www. journal.Ippm-stikesfa.ac.id/ojs/index.php/FHJ

ISSN 2088-673X | 2597-8667

Dari penelitian juga diketahui masih ada responden yang memiliki pendapatan kelas atas tapi memilih kelas keperawatan kelas 3 dan justru responden yang memiliki pendapatan kelas menengah memilih kelas keperawatan kelas 2 dan kelas 1. Hal ini disebabkan karena masih ada masyarakat yang meyakini bahwa kebutuhan untuk kesehatan bukan keperluan prioritas yang harus dipenuhi terlebih dahulu.

Menurut Pujianto (2008) suatu sistem kesehatan disebut dibiayai secara adil jika kontribusi terhadap total biaya kesehatan adalah sama untuk setiap masyarakat, sesuai dengan kemampuan masyarakat bersangkutan, tanpa memperhatikan status kesehatan atau tingkat penggunaan pelayanan kesehatan dari masyarakat tersebut, pembiayaan sistem pelayanan kesehatan yang adil berarti bahwa risiko yang dihadapi masyarakat untuk membiayai sistem kesehatan didistribusikan sesuai kemampuan membayar (ATP) masyarakat. Hal ini jelas berbeda dengan sebagian masyarakat Desa Sei Pancang Kecamatan Sebatik Utara yang memilih kelas pelayanan JKN belum sesuai dengan pendapatannya.

Pada penelitian ini diketahui pengeluaran masyrakat Desa Sei Pancang Kecamatan Sebatik Utara untuk keperluan sehari-hari masih lebih besar dibandingkan dengan pengeluaran untuk keperluan kesehatan, hal ini sesuai dengan pernyataan Pudjianto (2008) bahwa baik di perkotaan maupun di perdesaan, proporsi terbesar dari pengeluaran rumah-tangga adalah untuk makanan, dan pengeluaran untuk keperluan kesehatan tidak bersifat regresif.

\section{Hubungan Aksesibilitas dengan Pemilihan Kelas Kepesertaan JKN}

Aksesibilitas kesehatan terdiri dari biaya (biaya yang dikeluarkan dalam memperoleh pelayanan), jarak dan ketersedian transportasi (Muhazam, 2007). Andersen dalam Muhazam (2007) menyatakan bahwa tempat tinggal (terkait jarak) mempengaruhi pemanfaatan pelayanan kesehatan secara signifikan. Dalam penelitian ini diasumsikan bahwa semakin mudah aksesibilitas responden menuju pusat pelayanan kesehatan maka akan mempengaruhi responden dalam pemilihan kelas kepesertaan JKN. Hasil penelitian diketahui bahwa $99.4 \%$ responden menyatakan aksesibilitas pelayanan kesehatan di Pulau Sebatik adalah mudah untuk diakses dan dari hasil uji statistik disimpulkan tidak ada hubungan $(P$ Value $0,131>\alpha 0,05)$ yang bermakna antara responden yang menyatakan aksesbilitas mudah dan responden yang menyatakan aksesibilitas sulit dalam pemilihan kelas kepesertaan JKN.

Hasil analisis menunjukkan aksesibilitas tidak mempunyai hubungan yang bermakna dengan pemilihan kelas kepesertaan JKN, dalam hal ini disebabkan karena meskipun angkutan umum tidak ada untuk digunakan dalam mengakses pelayanan kesehatan yang ada di daerah Pulau Sebatik bukanlah suatu masalah karena responden menggunakan kendaraan pribadi untuk menggantikan angkutan umum dalam mencapai tempat pelayanan kesehatan, kemudian kondisi jalan penghubung ke tempat layanan kesehatan sudah baik, masyarakat yang mempunyai rumah yang jauh dengan pelayanan kesehatan tidak merasakan halangan untuk datang ke pelayanan kesehatan. Dengan jarak $\pm 5 \mathrm{Km}$ membutuhkan waktu \pm 10 menit untuk sampai ke tempat pelayanan kesehatan, dengan adanya kemudahan sarana transportasi dan prasanan jalan yang baik waktu tempuh ke tempat pelayanan kesehatan menjadi relatif singkat. Hasil penelitian ini sejalan dengan penelitian Wahyuni (2012) bahwa tidak ada hubungan aksesibilitas dengan pemanfaatan pelayanan kesehatan.

Secara umum jika melihat dari ukuran persentase, $99.4 \%$ responden menyatakan akses yang mudah dalam menjangkau pelayanan kesehatan di Pulau Sebatik baik, namun masih ada $0,6 \%$ responden menyatakan akses sulit. Hal ini bisa disebabkan oleh faktor lain diluar akses menuju ke tempat pelayanan kesehatan, seperti kondisi keuangan yang terbatas. Karman (2016) menjelaskan pemanfaatan pelayanan kesehatan dipengaruhi oleh akses pelayanan kesehatan, waktu yang harus dilalui untuk memperoleh pelayanan kesehatan, serta mudah atau tidaknya alat transportasi yang digunakan. Akan tetapi, untuk beberapa kondisi tertentu besarnya jarak tidak terlalu mempengaruhi akses lain (alat transportasi dan waktu tempuh). Kondisi keuangan yang terbatas lebih membuat responden memilih untuk tidak memanfaatkan pelayanan kesehatan yang ada. 


\section{Hubungan Mutu Pelayanan dengan Pemilihan Kelas Kepesertaan JKN}

Mutu pelayanan kesehatan adalah memenuhi dan melebihi kebutuhan serta harapan pelanggan melalui peningkatan yang berkelanjutan atas seluruh proses (Supriyanto, 2011). Penilaian mutu pelayanan kesehatan didasarkan pada lima dimensi mutu, diantaranya tangibles, reliability, responsiviness, assurance dan emphaty. Mutu pelayanan yang baik akan memberikan kepuasan pada pelanggan yang pada akhirnya pelanggan akan memanfaatkan dan merekomendasikan pelayanan kesehatan tersebut pada orang disekitarnya (Trimurthy, 2008). Sebaliknya jika masyarakat memiliki pengalaman yang buruk ketika memanfaatkan pelayanan kesehatan, membuat masyarakat beranggapan bahwa fasilitas kesehatan tidak dapat melayani dengan baik dan memenuhi harapan masyarakat (Nadiyah, 2017).

Pada peneilitian ini didapatkan 96,2\% responden menyatakan mutu pelayanan kesehatan yang ada di Pulau Sebatik dalam kategori baik, dan pada penelitian ini diasumsikan ada hubungan mutu pelayanan dengan pemilihan kelas kepesertaan JKN. Dari hasil uji statistik didapatkan hasil $(P$ Value 0,091 > $\alpha$ 0,05), dapat disimpulkan bahwa tidak ada hubungan yang berarti antara mutu pelayanan dengan pemilihan kelas kepesertaan JKN, dari hasil wawancara responden menyatakan mutu pelayanan tidak menjadi faktor utama dalam memilih kelas kepesertaan JKN, dikarenakan responden lebih mempertimbangkan pendapatan dalam memilih kelas kepesertaan JKN, responden lebih cenderung memilih pelayanan kesehatan yang sesuai dengan pendapatan mereka. Sebagaimana telah dijelaskan sebelumnya bahwa terdapat hubungan antara pendapatan dengan pemilihan kelas kepesertaan JKN, sehingga hal ini yang menyebabkan tidak ada hubungan antara mutu pelayanan dengan pemilihan kelas kepesertaan JKN.Hasil penelitian ini berbeda dengan penelitian Trimurthy (2008) yang menyatakan ada hubungan yang berarti antara mutu pelayanan dengan pemanfaatan pelayanan kesehatan, hasil penelitian juga berbeda dengan penelitian Anggraeni (2012) yang mengatakan terdapat pengaruh yang positif dengan mutu pelayanan kesehatan dengan pengambilan keputusan pasien dalam memilih jasa pelayanan kesehatan.

\section{Simpulan}

Berdasarkan hasil penelitian ini dapat disimpulkan bahwa ada hubungan antara pendapatan dengan pemilihan kelas kepesertaan Jaminan Kesehatan Nasional (JKN) di wilayah Desa Sei Pancang Kecamatan Sebatik Utara. Serta tidak ada hubungan antara aksesibilitas dan mutu pelayanan dengan pemilihan kelas kepesertaan Jaminan Kesehatan Nasional (JKN) di wilayah yang sama.

\section{Referensi}

Anggraeni, A. C. (2012). Asuhan Gizi Nutritional Care Process. Yogyakarta: Graha Ilmu.

Badan Pendidikan dan Pelatihan Keuangan Kementerian Keugan RI. http://bppk.kemenkeu.go.id/id/publikasi/arti kel/167-artikel-pajak/21-14-penghasilankelas-menengah-naik-potensi-pajak. Dikakses pada 1 April 2018.

Badan Penyelenggara Jaminan Kesehatan Nasional Cabang Kota Tarakan. (2018). Jumlah Kepesertaan Jaminan Kesehatan Nasional Wilayan Pulau Sebatik.

Badan Penyelenggara Jaminan Kesehatan Nasional. (2012). Peta Jalan Menuju Jaminan Kesehatan Nasional Tahun 2012-2019.

Badan Penyelenggara Jaminan Kesehatan Nasional. (2018). Jumlah Kepesertaan BPJS Kesehatan Tahun 2018. http://bpjskesehatan.go.id/bpjs/. Diakses tanggal 1 April 2018.

Karman. (2016). Faktor-faktor yang Berhubungan dengan Pemanfaatan Pelayanan Kesehatan bagi Masyarakat di Pesisir Desa Bungi Permai. Sulawesi Tenggara.

Kementerian Kesehatan RI. (2004). UndangUndang No 40 tentang Sistem Jaminan Kesehatan Nasional.

Muzaham, F. (2007). Memperkenalkan Sosiologi Kesehatan. Jakarta: Universitas Indonesia Press.

Nadiyah, H. (2017). Faktor-Faktor yang Berhubungan dengan Kepesertaan Program JKN di Wilayah Kerja Puskesmas Remaja Kota Samarinda. Jurnal Kebijakan Kesehatan Indonesia Vol 06.

Noerdjianto, D. (2015). Kajian Ability to Pay bagi Calon Peserta BPJS Kesehatan dalam Pemilihan Besar Iuran. Jambi. 
Faletehan Health Journal, 5 (3) (2018) 135-141 www. journal.Ippm-stikesfa.ac.id/ojs/index.php/FHJ

ISSN 2088-673X | 2597-8667

Pudjianto. (2008). Laporan Kajian Sistem Pembiayaan Kesehatan di Beberapa Kabupaten dan Kota Tahun 2008 (pp. 37-38). Jakarta.

Republik Indonesia. (1992). Undang-Undang No 24 Tahun 2011 tentang Badan Penyelenggara Jaminan Kesehatan Nasional. Sekretariat Negara. Jakarta.

Supriyanto. (2011). Mutu Pelayanan Kesehatan. Andi: Yogyakarta.
Trimurthy, I. (2008). Analisis Hubungan Persepsi Pasien tentang Mutu Pelayanan dengan Minat Pemanfaatan Ulang Pelayanan Rawat Jalan Puskesmas Pandanaran. Semarang.

Wahyuni, N. (2012). Faktor-Faktor yang Berhubungan dengan Pemanfaatan Pelayanan di Puskesmas. Balikpapan. 